\title{
Revealing Millennials' Networks in Discussing Maritime Issues within the Triple Helix of University-Industry-Government
}

\author{
Tatak Setiadi* \\ Department of Marine Transportation Engineering, Institut Teknologi Sepuluh Nopember, \\ Surabaya
}

Submitted: 28 October 2020 Accepted: 06 April 2021

\begin{abstract}
Millennials' networks within the triple helix of University-Industry-Government show unusual communication structures and are challenging to be revealed. Using the direct and online written interview with the millennials found about 817 relations (edges) to 347 actors (nodes) in total. Analysis by Social Network Analysis (SNA) found: (1) the dominant issues of the maritime human resources are about future work prospects and specialties field, imbalance of supply and demand of maritime human resources, and improvement needed of industry's human resources (2) the dominant skill issue is capacity building and continuous learning, (3) the highest degree of centrality and closeness centrality has resulted from Industry, (4) the highest betweenness centrality and eigenvector centrality has resulted from University, (5) there is moderate positive correlation of ages to closeness centrality and weak negative correlation to eigenvector centrality, (6) there is a moderate positive correlation of education levels to closeness centrality, (7) there is a weak negative correlation of gender to eigenvector centrality, and (8) there is a statist relation of the triple helix in discussing maritime issues.
\end{abstract}

Keywords: Centrality; Communication; Millennials; Organization; Social Network Analysis (SNA)

\section{Introduction}

The millennial generation, who was born about 1980 until 2000, is being worldwide issues since their presences dominate the world's population, and it is also well-known for its unique characters. National Social-Economic Survey (Susenas) of Statistics Indonesia 2017 noted that millennials' growth in Indonesia reaches 33,75\% of Indonesia's population. It is more significant than other generations' growth, such as baby boomers, generation-x, and generation-z (Budiati, et al., 2018). This evidence becomes a particular case of the organization somehow. For instance, in Indonesia, their existence became our governmental considerations by putting millennials into the ministries position and putting them into the president's specialized staff (Hendartyo \& Wibowo, 2019).

\footnotetext{
"Corresponding email: tatak.setiadi@gmail.com
} 
Research showed at least three ways of approaching millennials' growths and their paths into organizations. First, organizations today are not only accompanying millennials through their high motivation of working, technology-savvy, and high achievement but also accompanying them in terms of giving guidance and advice (Myers \& Sadaghiani, 2010). Second, some also argued that millennials need help developing their communication competencies, such as interpersonal communication skills, negotiation and conflict management skills, and networking skills (Hartman \& McCambridge, 2011). Third, millennials tend to be less attracted to the workplace with strict rules and fewer appreciations (Gong, Greenwood, Hoyte, Ramkissoon, \& He, 2018).

Nationwide, The Government of Indonesia (GOI) empowered this situation to action into Indonesia's vision: Indonesia's Advance with Qualified Human Resources (SDM Unggul untuk Indonesia Maju). By Indonesia's spirit as the World Maritime Axis, in 2020, implementations of that vision are conducted by upgrading Indonesia's maritime human resources. This vision has already included in the ocean policy document (Presidential Decree of The Republic of Indonesia Number 16 the Year 2017 Concerning Indonesian Ocean Policy, Pub. L. No. Number 16 the Year 2017, 2017). It was also mentioned in The Ministry of National Planning strategic planning document (Kementerian Perencanaan Pembangunan Nasional/Badan Perencanaan Pembangunan Nasional, 2019).

In terms of upgrading the educational sector, the Department of Marine Transportation Engineering, one of the maritime programs in colleges, provides a curriculum that complies with maritime aspects, such as port, shipping, and maritime logistics. On the other hand, an expert once stated that education is required to build self-capacity (Kartasasmita, 1994). At that time, universities' education took too much control and causing much unapplicable research for industries. Therefore, to cope with that, there must be potential cooperation within the three elements, University-Industry-Government, such as the Department of Marine Transportation Engineering's helixes as the University or education sector, PT. Pelabuhan Indonesia III (Persero) as the Industry, and Port Authority of Tanjung Perak as the Government. Furthermore, the most important is that by this triple helix framework, the structure of millennials' networks within them will be found by sociogram maps, which could be in the form of persons, groups, and organizations (Bennett \& Segerberg, 2012)

\section{Literature Review}

Several studies concern with millennials' growths. The research of millennials' participation during Finlandia's political situation (Huttunen \& Christensen, 2019). Moreover, there are also researches studying millennial disruptions in giving a new atmosphere in medicine and midwifery fields (Mercer, 2018); (Erlam, Smythne, \& Wright-St Clair, 2018). However, Weber emphasized that the most important of studying millennials is their hard work and skill in a specific field (Weber, 2017). It made them looked like a narcissistic generation rather than a can-do generation.

A group of researchers understood those as ways for millennials to connect to others (Bergman, Fearrington, Davenport, \& Bergman, 2011). Using these connections, an organization could empower it to map actors who most likely become the center of attention to link other 
groups (Eisenberg, Johnson, \& Pieterson, 2015). As Devito stated, each organization's members would have a closer relationship within these networks (Devito, 2015). By using a sociological name generator, the research found actors related to a specific issue. And then, it is mapped into who plays as collaborators and who plays as external networks.

The ideal form of connection or communication network within an organization is when every actor has the same relationship. In a network, the actors are called nodes, and the relations are called links or edges (Dijk, 2006). The actor and its connections have specific communication relationships, such as degree centrality, closeness centrality, betweenness centrality, and eigenvector centrality (Monge and Contractor, 2003, as cited in Zwijze-Koning \& de Jong, 2015); (Marsden, 2005). A decade ago, some researchers had noticed that these networks contributed to discussing certain actors in a network, mapping relations of actors, mapping relationships (dyad, triad, subgroup, and group), and discussing social networks of certain actors (Wasserman \& Faust, 1994). Therefore, the triad relation is suitable for the triple helix framework. The triad or triple helix will put each actor the same importance by its character of two-way communication flow, which has numbers of valued information (Etzkowitz, 2008).

\section{Methodology}

The research used a quantitative approach by measuring centrality values of relationships established by actors discussing the development of maritime human resource issues within the triple helix of the Department of Marine Transportation Engineering, PT. Pelabuhan Indonesia III (Persero), and Port Authority of Tanjung Perak. Data were collected through direct and online written interviews with a sociological name generator to find actors and their relations and then processed by using Gephi to put their links into a sociogram map. At first, data were collected directly from millennials at the Department of Marine Transportation Engineering. The department's data is filtered to obtain millennials' participants using Berger's ages character (Berger, 2018).

The second and third data were obtained through a written interview using an online questionnaire since the industry and the Government prohibited any visitation concerning health issues. Data from these organizations is filtered to obtain millennials' participation as well. From those three organizations resulted in about 817 relations among 347 actors discussing maritime human resources. These networks were analyzed using Social Network Analysis (SNA) method to find the centralities of the whole network and find centralities of each organization. And then, each organization was also researched to find its core networks. These three core networks were unified to obtain the core networks of the triple helix network. Descriptive analysis was then conducted to describe the networks and find the relation of millennials' characteristics toward the centrality values. 


\section{Categorization of Information about Developing Maritime Human Resource}

Issues of the development of maritime human resources could be grouped into two clusters. First is the problem of the general cases. Second is the issue of competencies that every maritime human resource should master. At the first cluster, the general issues known by the millennials are $32 \%$ issues of the human resource itself, including the prospect of posts in the maritime sector and its specialized subject, the imbalance of supply and demand of the maritime human resource, and the needs of the industry to improve its human resource. Then, marine and its potential $21 \%$, maritime technology issue $16 \%$, maritime news updates $17 \%$, millennials in maritime field $9 \%$, and issues of regulations $5 \%$.

At the second cluster, the collected data are compared to the International Maritime Organization (IMO)'s framework of competencies of maritime human resources competencies (IMO, 2009). The most frequent occurrences that are by $45 \%$ were the competencies of capacity building and continuous learning. Included in these competencies are the skill of port operation, mastering software for design (such as ship design, port design, and marine transportation design), and the application of any expertise subject (such as management, accountancy, logistics, and data science). It is followed by problem-solving and decision-making skills $16 \%$, management and leadership skills $15 \%$, communication skills $10 \%$, adaptation skills $7 \%$, and teamwork skills $6 \%$.

\section{Core Networks within the Triple Helix}

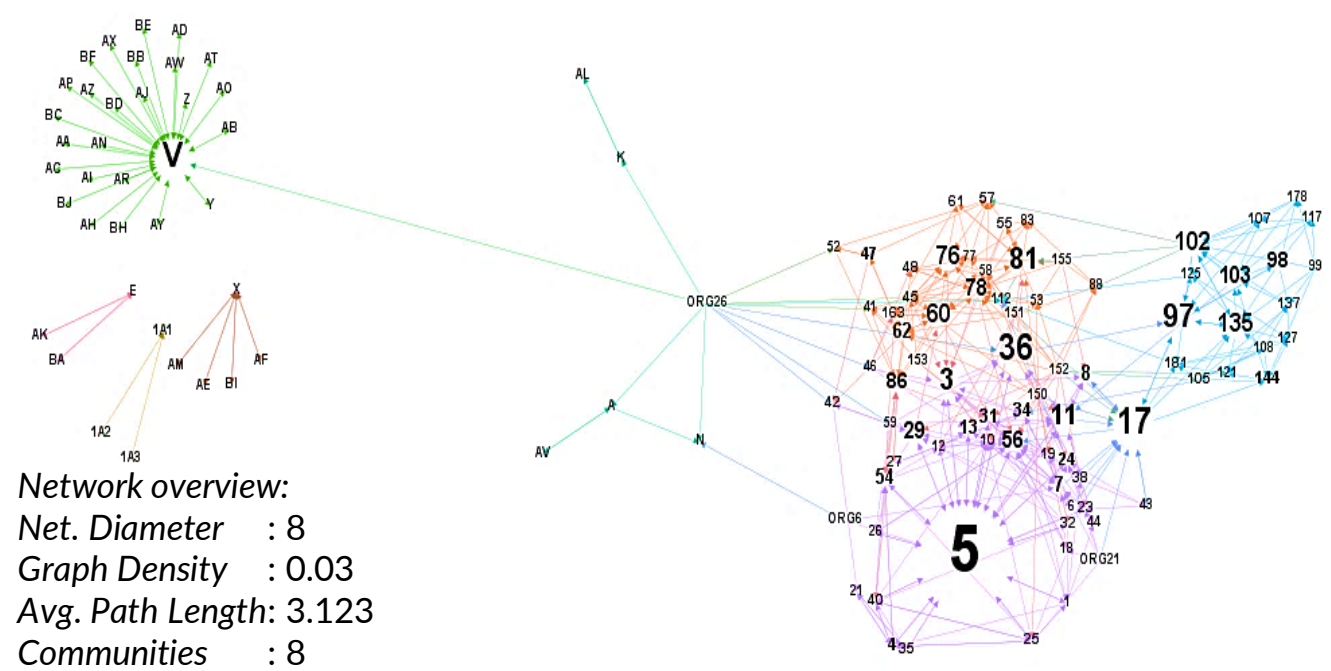

Figure 1.

Core Networks within the Triple Helix.

(Source: Author's compilation)

From the finding of information clusters, the analysis is narrowed into the discussion of the core networks. These networks are formed of those actors who have the highest value of betweenness centrality from each group, University, Industry, and Government. It is found that the networks have 123 actors who established about 457 relations discussing maritime human resources with network diameter 8 , average path length 3,123, network density 0,03 , and 
communities formed 8. Meaning that every actor has about three steps to reach the actor with sufficient information, and the furthest steps actors must through are eight actors-length. Also, it means that these networks are about having $0,3 \%$ only of the whole possible relations. Actor $\mathrm{V}$ has the highest degree of centrality and closeness centrality, and Actor 5 has the highest betweenness centrality and eigenvector centrality. Looking at the core network, these two actors were grouped in different directions. Actor $\mathrm{V}$ tends to make a group with relatives in the workplace, while Actor 5 tends to group with actors from University and organization like Actor ORG21.

Three main actors have specific values within the networks, such as Actor 5 (from the University) with betweenness centrality and eigenvector centrality, Actor V from the Industry with degree centrality and closeness centrality, and certain actor from the Government with eigenvector centrality. Actor 5 is a member of the student association in the Department of Marine Transportation Engineering. He actively participates in the Communication and Information Division within the student association. Bore with this kind of role, it is potentially correct that this actor has the highest betweenness centrality and eigenvector centrality for his or her relations, which may be connected to many actors, including certain actors with unique characteristics roles and positions.

On the other hand, with his expertise background in the Operational Division and years of experience in the company, Actor $\mathrm{V}$ showed the highest centrality and closeness centrality. Looking at the network, Actor $\mathrm{V}$ tends to be in a group with relatives within the company. Moreover, some come from other divisions and another group of ages and positions in the company among these relatives. Furthermore, Actor $1 \mathrm{~A} 1$ from the Government has the highest eigenvector centrality in its group. It could be caused by the actor's responsibility of Public Relations for the Port Authority of Tanjung Perak. Actor 1A1 may know and connect to actors who have strategic positions and link to some public figures by this role.

\section{Relationship of Respondents' Characteristics and Centrality Values}

Table 1.

Correlation of Respondents' Characteristics to Centrality Values.

\begin{tabular}{clcccccccc}
\hline \multirow{2}{*}{ No } & \multirow{2}{*}{ Characters } & \multicolumn{2}{c}{$d c$} & \multicolumn{2}{c}{$c c$} & \multicolumn{2}{c}{ bc } & \multicolumn{2}{c}{$e c$} \\
\cline { 3 - 9 } & & cor & $p$-value & cor & $p$-value & cor & $p$-value & cor & $p$-value \\
\hline 1 & Age & -0.098 & 0.418 & 0.487 & 0.000 & -0.113 & 0.351 & -0.254 & 0.034 \\
2 & Education & 0.033 & 0.783 & 0.65 & 0.000 & -0.084 & 0.49 & -0.184 & 0.128 \\
3 & Gender & -0.166 & 0.168 & -0.12 & 0.322 & -0.121 & 0.318 & -0.373 & 0.001 \\
\hline
\end{tabular}

Notes: $\mathrm{dc}=$ degree centrality, $\mathrm{cc}=$ closeness centrality, $\mathrm{bc}=$ betweenness centrality, $\mathrm{ec}=$ eigenvector centrality.

(Source: Author's compilation)

The correlation test of age to the centrality is as follows; age has a moderate positive correlation to closeness centrality, and age has a weak negative correlation to eigenvector centrality. It means that the higher the actor's age, the higher its closeness centrality, and the lower the age of the actor, the higher its eigenvector centrality. The correlation test showed 
that education level has a moderate positive correlation to closeness centrality for the characteristic of education level. In other words, the higher the level of education of an actor, the higher its closeness centrality. Gender is also correlating centrality. In this case, female actors tend to less in having eigenvector centrality. In contrast, male actor tends to have higher eigenvector centrality, which means that female actors tend to be less popular than male actors.

\section{Discussion}

Issues flown in the helixes of University-Industry-Government depicted that millennials have particular attention to maritime human resources. Millennials' age participating in this research are ranged from 20 years old until 39 years old. According to Acts of The Republic of Indonesia Concerning Manpower (Acts of The Republic of Indonesia Number 13 the Year 2003 Concerning Manpower, Pub. L. No. Number 13 the Year 2003), those age ranges are including in job seeker ages. This evidence is somehow will become a particular case for the organization. A global analytics and advice firm found out millennials tend to have empathy and adaptability, look at the big picture of an organization, and always being watched by the supervisor regarding their performance (Gallup, 2016). Moreover, at the same time, they also tend to be open to other available posts.

The triple helix framework within the University-Industry-Government contributes to improving innovation in a particular field (Guerrero \& Urbano, 2016, as cited in de Almeida Borges, de Araújo, Lima, Ghesti, \& Souza Carmo, 2020). For example are (1) the openness of access through interactions to the industry, (2) the industry's access related to funding will contribute to valuable innovations, and (3) government will play a role in influencing the business atmosphere. The Ministry of National Planning in 2019 had already arranged formulas that are developing strategies such as industry-based vocational education and training (VET) and developing competencies certification.

In fact, among issues arranged by the government, millennials in this research tend to focus on the need for industry or company to upgrade their human resources capacity and work prospect and specialization area in the maritime field. Furthermore, they concern the competency of knowledge of port activities, the ability to operate design software, and the ability to perform specific expertise like management, accountancy, logistics, and data science. These concerns are related to Indonesia's existing condition, challenging many obstacles, especially in the maritime-related sector. For examples are technical matters in ports, the usage of the insufficient ship for shipping, the lack of loading from Tol Laut's regions target (meaning that there are no exchanges of product to be brought), and the lack of the use of information technology for the maritime logistics sector. Furthermore, looking at the distribution of issues, the university and industry share the same maritime technology problem.

Practically, industries have used a specific online portal called Inaportnet, which will assist in data sharing related to port facilities (Inaportnet, 2013). By using this integrated system, it is aimed there will be no case of two stakeholders like port operators and business actors. However, it happened in 2019; that is when the port operator (Groups of Pelabuhan Indonesia) is found not to provide any information system integrated with the Inaportnet portal. We could 
see a relatively weak role from the regional government related to the port authority concerning this issue. Therefore, it requires reactivating and reinforcing Government Regulation's application on Port Affairs (Government Regulation of The Republic of Indonesia Number 61 the Year 2009 Concerning Port Affairs, Pub. L. No. Number 61 the Year 2009). Inside is stated that the government's port authorities have the steady power to control and manage every port activity. Millennials best describe it by commenting on the competency of port activities' knowledge as a core competence for maritime human resources. Like in university, they are concerned about the need of industry or company to upgrade their human resources capacity. Moreover, they also concern about future work prospects in the maritime sector.

Results showed that the higher the actor's age, the higher the closeness centrality, and the lower the actor's age, the higher eigenvector centrality. It is shown that Actor $V$ has the highest degree of centrality and closeness centrality. According to data, Actor V is older than Actor 5. There is correlation research finding that age correlates to closeness centrality (Sulistiawati, P Lubis, \& Mulyani, 2014). In research, they argued that this evidence occurred due to an actor's older and more mature age, meaning that it is easier to reach. Therefore, the finding supports the correlation test results. In the sociogram map, Actor V looked to have many relations with other actors inside the company. As other researchers had studied, this relation is the type of socio-political relation, which means that each actor in these relations shared its same interests, especially maritime human resources (Choi \& Park, 2015).

Furthermore, the same with eigenvector centrality, Actor 5 has the highest eigenvector centrality. It is also supporting the correlation test result. It is showed in the map by its relations to other actors who also have a certain kind of centrality, as the actor from the Human Resources Division of the student association (SA), the actor from the Science and Profession Division of the SA, and the actor from External Relation Division of the SA.

The research found that the female actors tend to have lower eigenvector centrality than the male actors. There is maybe one reason to describe this. Some stated that female actors' willingness most likely causes this evidence to become a competitor of other actors in a group or an organization (Beugnot, Fortin, Lacroix, \& Villeval, 2019). It is proven in the sociogram map that there are a few female actors who played the role of particular centrality. At the education level character, the correlation stated that the higher the education level of an actor, the higher the closeness centrality. It is somehow important to be understood that one kind of self-esteem is education.

However, the opinion of education being one's self-esteem had already come up in the last decades. Griffiths even stressed this self-esteem because of hard work through training and other exercises and as one's belonging value (Griffiths, 1993). Using this perspective means that the lower the education level, the lower the closeness centrality. Moreover, it is supported by the facts that Actor V comes with a Master's degree level, while Actor 5 with a Senior High level. In an organization, this education level is also determining one's position somehow. With higher education, especially in a company, an actor will become the organization's priorities to be empowered for the company and has little chance to connect with other organizations, such as universities and government.

Inside the network, there is one actor whose position is between the two groups, Industry and University, Actor ORG26. Actor ORG26 is PT. Pelabuhan Indonesia III (Persero) 
itself. And one actor around the University Group, Actor ORG6. Actor ORG6 is part of a government organization at the regional level, the Port Authority of Tanjung Perak. In this case of discussing maritime human resources development, Actor ORG26 became the information source for industry actors or its organization and university actors. Meanwhile, there is actor $\mathrm{N}$ who gets the issues from Industry and Government. This sociogram map then gives us evidence that there is an imbalance relation within this triple helix collaboration.

However, Etzkowitz called this condition a statist triple helix due to the ideal relation within the triple helix, a two-way interaction that did not work (Etzkowitz, 2008). Some researchers added that this kind of relation would impact an organization whose position is relatively weak (Uysal, Yang, \& Taylor, 2018). This condition may lead people to think that university is a means of the skilled human resource provider rather than a strategic part of the discussion about maritime human resources. Moreover, it could even worsen. As researched by Liu and teams, they found that the university's popularity causes this less interaction (Liu, Liu, \& Luo, 2018). They argued that universities in a small town would be less likely to form a triple helix collaboration of University, Industry, and Government because the universities are looked less promising in creating innovations.

\section{Conclusion}

Most millennials within the triple helix of the University-Industry-Government are concerned with future work prospects and maritime specialties, the lack of maritime human resources and the need for industries to improve their human resources' capacity. In terms of competency, millennials suggest the knowledge of ports in the first place. Second, the ability to operate design software related to shipping design, port design, marine transportation network design, and applying specific expertise such as management, accountancy, logistics, and data science. Millennials also have some centrality values. The highest degree centrality and closeness centrality are by Actor $V$ from Industry, and the highest betweenness centrality and eigenvector centrality are acknowledged by Actor 5 from University. To sum up their potential in the organization, the organization's management could consider a younger millennial who has a higher education level and take certain vital positions related to its strategic information. Also, to maximize the opportunities within a triple helix, it will be wiser to discuss and rearrange the interaction to get a better two-way communication direction.

\section{Acknowledgment}

The author would like to thank Prof. Y.A. Nunung Prajarto, M.A., Ph.D, for his advice during the research. The author would also like to thank Scholarship Program from The Ministry of Research, Technology, and Higher Education of the Republic of Indonesia (Program Beasiswa PasTi, Kementerian Riset, Teknologi, dan Pendidikan Tinggi Republik Indonesia) for the support in this research. 


\section{References}

Acts of The Republic of Indonesia Number 13 the Year 2003 Concerning Manpower, Pub. L. No. Number 13 the Year 2003. (2003).

Bennett, W. L., \& Segerberg, A. (2012). The logic of connective action: Digital media and the personalization of contentious politics. Information Communication and Society, 15(5), 739-768. https://doi.org/10.1080/1369118X.2012.670661.

Berger, A. A. (2018). Cultural Perspectives On Millennials. London, UK: Palgrave Macmillan. https://doi.org/10.1007/978-3-319-69685-0.

Bergman, S. M., Fearrington, M. E., Davenport , S. W., \& Bergman, J. Z. (2011). Millennials, narcissism, and social networking: What narcissists do on social networking sites and why. Personality and Individual Differences, 50(5), 706-711. https://doi.org/10.1016/j.paid.2010.12.022.

Beugnot, J., Fortin, B., Lacroix, G., \& Villeval, M. C. (2019). Gender and peer effects on performance in social networks. European Economic Review, 113, 207-224. https://doi.org/10.1016/j.euroecorev.2019.01.002.

Choi, S., \& Park, H. W. (2015). Networking Interest and Networked Structure: A Quantitative Analysis of Twitter Data. Social Science Computer Review, 33(2), 145-162. https://doi.org/10.1177/0894439314527054.

de Almeida Borges, P., de Araújo, L. P., Lima, L. A., Ghesti, G. F., \& Souza Carmo, T. (2020). The triple helix model and intellectual property: The case of the University of Brasilia. World Patent Information, 60(December 2019), 101945, https://doi.org/10.1016/j.wpi.2019.101945.

Devito, J. A. (2015). Human Communication: The Basic Course Thirteenth Edition. London, UK: Pearson

Dijk, J. V. (2006). The Network Society. Social Aspects of New Media. Thousand Oaks, CA: SAGE Publications

Eisenberg, E. M., Johnson, Z., \& Pieterson, W. (2015). Leveraging social networks for strategic success. International Journal of Business Communication, 52(1), 143-154. https://doi.org/10.1177/2329488414560283.

Erlam, G., Smythne, L., \& Wright-St Clair, V. (2018). Action research and millennials: Improving pedagogical approaches to encourage critical thinking. Nurse Education Today, 61(May 2017), 140-145. https://doi.org/10.1016/j.nedt.2017.11.023.

Etzkowitz, H. (2008). The Triple Helix: University-Industry-Government Innovation and Entrepreneurship. London, UK: Routledge. https://doi.org/10.4324/9781315620183.

Gallup. (2016). How Millennials Want to Work and Live. Retrieved from https://enviableworkplace.com/wp-content/uploads/Gallup-How-Millennials-Want-ToWork.pdf

Gong, B., Greenwood, R. A., Hoyte, D., Ramkissoon, A., \& He, X. (2018). Millennials and organizational citizenship behavior: The role of job crafting and career anchor on service. Management Research Review, 41(7), 774-788. https://doi.org/10.1108/MRR-05-2016-0121.

Government Regulation of The Republic of Indonesia Number 61 the Year 2009 Concerning Port Affairs, Pub. L. No. Number 61 the Year 2009. (2009).

Griffiths, M. (1993). Self-identity and Self-esteem: Achieving equality in education. Oxford Review of Education, 19(3), 301-317. https:// doi.org/10.1080/0305498930190304.

Hartman, J. L., \& McCambridge, J. (2011). Optimizing millennials' communication styles. Business $\begin{array}{lllll}\text { and Professional Communication } & \text { Quarterly, } & 74(1), & 22-44 .\end{array}$ https://doi.org/10.1177/1080569910395564.

Hendartyo, M., \& Wibowo, K. S. (2019). Setelah Mengumumkan 7 Milenial, Jokowi Kini Punya 14 Staf Khusus. November 22, 2019, retrieved from 
https://nasional.tempo.co/read/1275139/setelah-mengumumkan-7-milenial-jokowi-kinipunya-14-staf-khusus

Huttunen, J., \& Christensen, H. S. (2019). Engaging the Millennials: The Citizens' Initiative in Findland. Young, 28(2), 175-198. https://doi.org/10.1177/1103308819853055.

IMO. (2009). IMO COMPETENCY FRAMEWORK. Retrieved from https://newunkampus.unssc.org/pluginfile.php/105615/mod folder/content/0/Agency \%20Leadership\%20Frameworks/IMO/IMO\%20Competency\%20Framework.pdf?forcedo wnload $=1$

Inaportnet. (2013). Tentang Inaportnet. June, 26, 2013, retrieved from http://portal.inaportnet.com/about.html

Kartasasmita, G. (1994). Pembangunan Sumber Daya Manusia Iptek dan Peranannya dalam Pembangunan Nasional. Bandung: Penerbit ITB.

Kementrian Perencanaan Pembangunan Nasional/Badan Perencanaan Pembangunan Nasional. (2019). Rancangan Rencana Pembangunan Jangka Menengah Nasional (RPJMN) 20202024. In Rencana Pembangunan Jangka Menengah Nasional 2020-2024. Kementrian PPN/Bappenas.

Liu, D., Liu, X., \& Luo, W. (2018). The University-Industry-Government Triple Helix Innovation model with Innovation and Entrepreneurship Base as the Node. International Conference on Education, Management, Arts, Economics and Social Science, 264(Icemaess), 583-587. https://doi.org/10.2991/icemaess-18.2018.117.

Marsden, P. V. (2005). Recent Developments in Network Measurement. In Models and Methods in Social Network Analysis (pp. 8-30). Cambridge, UK: Cambridge University Press.

Mercer, C. (2018). How millennials are disrupting medicine. CMAJ: Canadian Medical Association Journal = Journal de l'Association Medicale Canadienne, 190(22), E696-E697. https://doi.org/10.1503/cmaj.109-5605.

Myers, K. K., \& Sadaghiani, K. (2010). Millennials in the workplace: A communication perspective on millennials' organizational relationships and performance. Journal of Business and Psychology, 25(2), 225-238. https://doi.org/10.1007/s10869-010-9172-7.

Presidential Decree of The Republic of Indonesia Number 16 the Year 2017 Concerning Indonesian Ocean Policy, Pub. L. No. Number 16 the Year 2017. (2017).

Sulistiawati, A., Lubis, D. P., \& Mulyani, E. S. (2014). Analisis Jaringan Sosial dalam Gabungan Kelompok Tani (Gapoktan) Tani Berkah. Sodality: Jurnal Sosiologi Pedesaan, 2(2), 76-82. https://doi.org/10.22500/sodality.v2i2.9415.

Uysal, N., Yang, A., \& Taylor, M. (2018). Shareholder communication and issue salience: corporate responses to 'social' shareholder activism. Journal of Applied Communication Research, 46(2), 179-201. https://doi.org/10.1080/00909882.2018.1437643.

Wasserman, S., \& Faust, K. (1994). Social Network Analysis: Methods and Applications. Cambridge, UK: Cambridge University Press

Weber, J. (2017). Discovering the Millennials' Personal Values Orientation: A Comparison to Two Managerial Populations. Journal of Business Ethics, 143(3), 517-529. https://doi.org/10.1007/s10551-015-2803-1.

Zwijze-Koning, K. H., \& de Jong, M. (2015). Network Analysis as a Communication Audit Instrument: Uncovering Communicative Strength and Weakness Within Organizations. Journal of Business and Technical Communication, 29(1), 36-60. https://doi.org/10.1177/1050651914535931. 